NSWC/WOL TR 77.90

\title{
FISH KILLING POTENTIAL OF A CYLINDRICAL CHARGE EXPLODED ABOVE THE WATER SURFACE
}

BY JOHN F. GOERTNER

RESEARCH AND TECHNOLOGY DEPARTMENT

12 DECEMBER 1978

Approved for public release, distribution unlimited.

NAVAL SURFACE WEAPONS CENTER

Dahlgren, Virginia 22448 - Silver Spring, Maryland 20910 

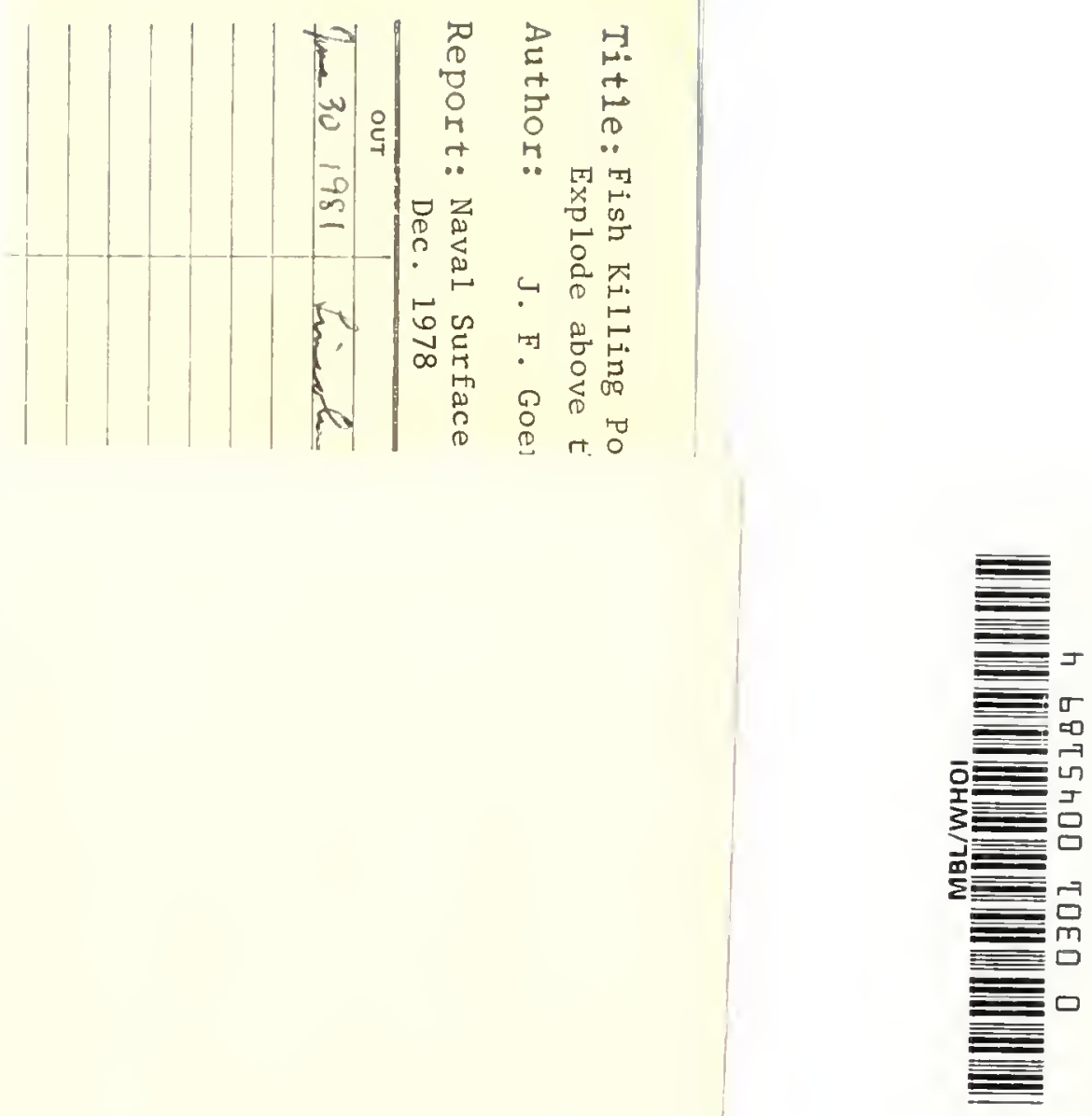


\begin{tabular}{|c|c|}
\hline REPORT DOCUMENTATION PAGE & $\begin{array}{l}\text { READ INSTRUCTIONS } \\
\text { BEFORE COMPLETING FORM }\end{array}$ \\
\hline $\begin{array}{l}\text { I REPORT NUMBER } \\
\text { NSWC/WOL TR 77-90 }\end{array}$ & $\begin{array}{ll}3 & \text { RECIPIENT'S CATALOG NUMBER } \\
\end{array}$ \\
\hline \multirow[t]{2}{*}{$\begin{array}{l}\text { TITLE (and Subltle) } \\
\text { Fish Killing Potential of a Cylindrical } \\
\text { Charge Exploded Above the Water Surface }\end{array}$} & $\begin{array}{r}\text { 5. TYPE OF REPCRT } \triangle \text { PERIOD COVEREO } \\
\text { Final }\end{array}$ \\
\hline & 6. PERFORMING ORG. REPORT NUMBEA \\
\hline $\begin{array}{l}\text { 7. AUTHOR(s) } \\
\text { John F. Goertner }\end{array}$ & 8. CONTRACT OR GRANT NUMBER( $(\cdot)$ \\
\hline $\begin{array}{l}\text { PERFORMING ORGANIZATION NAME ANO AODRESS } \\
\text { Naval Surface Weapons Center } \\
\text { White Oak, Silver Spring, Maryland } 20910\end{array}$ & $\begin{array}{l}\text { 10. PROGRAM ELEMENT, PROJECT, TASK } \\
\text { AREA WORK UNIT NUMBERS, } \\
63721 \mathrm{~N} ; \text { SO400; S040001; } \\
\text { CRI4CA501 }\end{array}$ \\
\hline \multirow[t]{2}{*}{ 11. CONTROLLING OFFICE NAME ANO ADORESS } & $\begin{array}{l}\text { 12. REPORT OATE } \\
12 \text { December } 1978\end{array}$ \\
\hline & $\begin{array}{c}13 \text { NUMBER OF OAGES } \\
39\end{array}$ \\
\hline \multirow[t]{2}{*}{14 MONITORING AGENCY NAME AOORESS(If differene from Controlling OIflce) } & $\begin{array}{l}\text { 15. SECURITY CLASS. (of thlo report) } \\
\text { UNCLASSIFIED }\end{array}$ \\
\hline & $\begin{array}{l}\text { ise. OECLASSIFICATION DOWNGRADING } \\
\text { SCHEOULE }\end{array}$ \\
\hline
\end{tabular}

16 OISTRIBUTION STATEMENT (Ol this RopOIt)

Approved for public release, distribution unlimited.

17. DISTRIBUTION STATEMENT (ot the ebstrect entered in Block 20, It different from Report)

18. SUPPLEMENTARY NOTES

19. KEY WOROS (Continue on revorse ide it neceasary and ldently by block numbor)

Explosions Lethal Ranges

Airburst

Underwater Explosions

Swimbladder Fish

Fish-kill

20. ABSTRACT (Continue on reverso alde if noceseory and identity by block numbor)

Two special air-burst test geometries are compared with two

typical underwater explosion test geometries in order to determine the relative hazard to swimbladder fish. The method consists of approximate calculations for extreme values of compression and extension of the fishes' gas-filled swimbladder in response to the explosion pressure waves. The kill probability is then calculated from the ratio of maximum to minimum radius during the oscillatory response using an experimentally determined function. (Cont.) 
Calculations are made for $1000-1 \mathrm{~b}$ and $64,000-1 \mathrm{~b}$ cylinders of $\mathrm{H}-6$ explosive $(\mathrm{L} / \mathrm{D}=3.65)$ fired end-on, 1.3 diameters from the water surface. By assuming a uniform fish-density distribution throughodt the water it is estimated that on the basis of fish-killed/kg explosive a typical underwater explosion is some 1000 times more hazardous for killing fish than these air-burst tests. 


\section{SUMMARY}

This report deals with the prediction of explosion injury to fish with swimbladders and is part of a continuing study of the effects of underwater explosions on marine life. Swimbladder fish are particularly vulnerable to explosions, and this group includes the majority of fish with sports and commercial value. This study will result in an improved capability to predict such effects, and will be useful in connection with the testing of new explosives and warheads at sea. The case considered here is an application of a general method developed at the Naval Surface Weapons Center to a special test configuration in which the explosive charge is above the water surface.

This study is part of the ordnance pollution abatement program of the Naval sea systems Command and was supported by Task

SEA $55001 / 19373$.

The author is indebted to George A. Young and Ermine A. Christian for valuable suggestions during the course of this work.

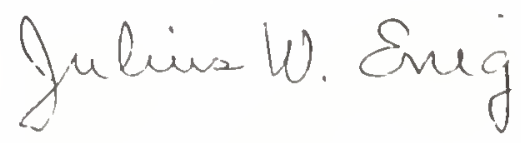

JULIUS W. ENIG

By direction 


\section{CONTENTS}

1. INTRODUCTION ............................. 5

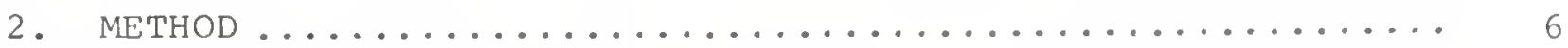

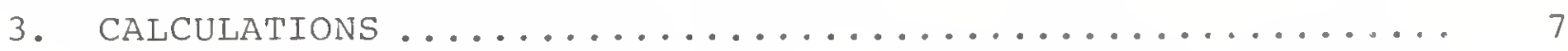

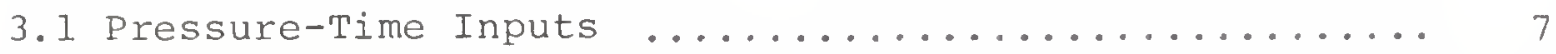

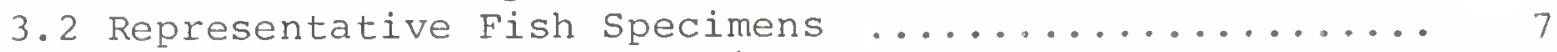

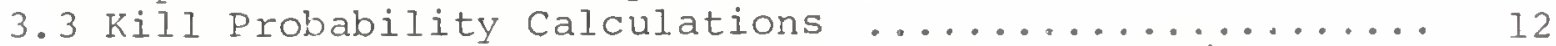

3.4 Response to Exponential waves of Short Duration...... I3

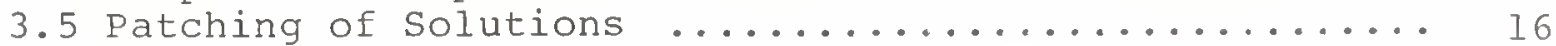

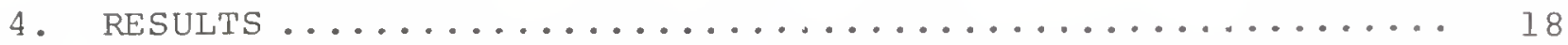

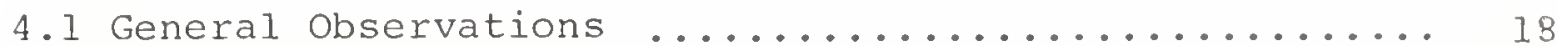

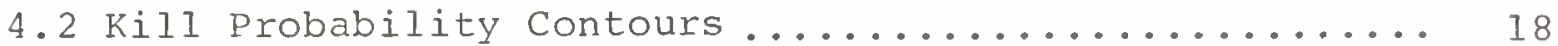

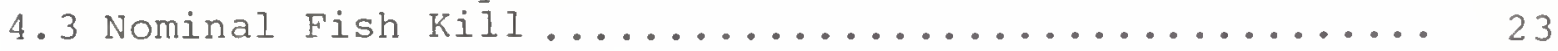

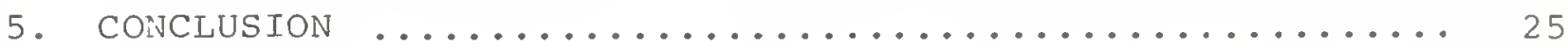

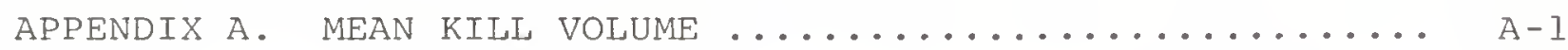




\section{ILLUSTRATIONS}

Figure

Page

2.1

3.1 .1

3.1 .2

4. 2.1

4.2 .2

Underwater Pressure-Time Signatures Measured on $8-1 \mathrm{~b}$ Tests $(\mathrm{HOB}=0.28 \mathrm{~m}) \ldots \ldots \ldots \ldots \ldots \ldots \ldots \ldots \ldots \ldots \ldots \ldots . \ldots \ldots$ Sketch Showing Pressure-Time Signatures Used to Calculate Kill Probabilities (1000 lb $\mathrm{H}-6$; Horizontal Range $=18.3$ meters $\ldots \ldots \ldots \ldots \ldots$ sketch Showing Pressure-Time Signatures Used to Calculate Kill Probabilities $(64,000$ lb $\mathrm{H}-6$; Horizontal Range $=73.2$ meters) $\ldots \ldots \ldots \ldots \ldots . . . .11$ Comparison of Predicted Kill probability for 1000-1b Air Burst Test with Contours Calculated for $0.57 \mathrm{~kg}$ Pentolite at

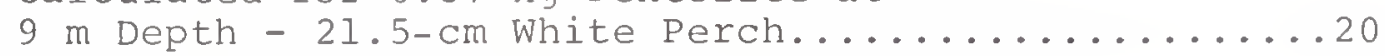
Comparison of Predicted Kill Probability for $64,000-1 b$ Air Burst Test with Contours Calculated for $32 \mathrm{~kg}$ Pentolite at

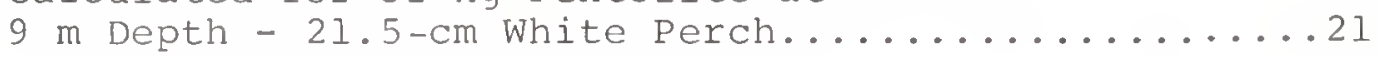

\section{TABLES}

Table

1.1

3. 2.1

3. 5.1

4.2 .1

$4 \cdot 3 \cdot 1$

$4 \cdot 3.2$

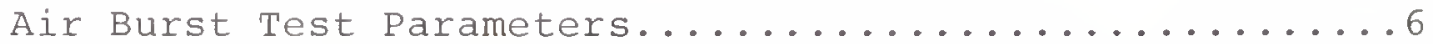

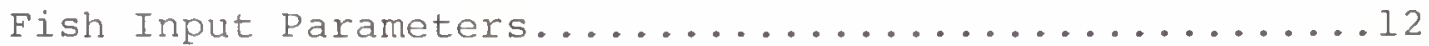

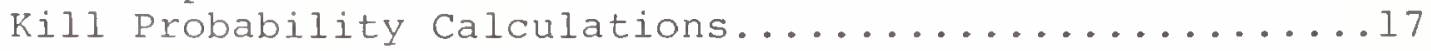
Variation of Kill Probability as a Function

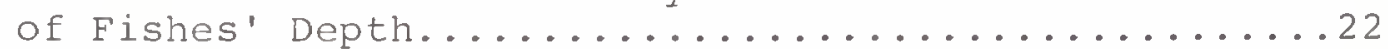
Water Volumes Enclosed by kill probability

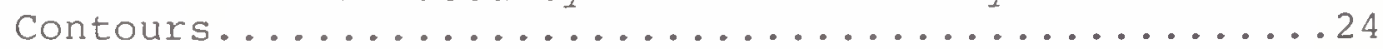

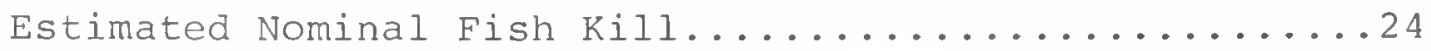


FISH KILLING POTENTIAL OF A CYLINDRICAL CHARGE

EXPLODED ABOVE THE WATER SURFACE

\section{INTRODUCTION}

The Naval surface Weapons Center is currently carrying out a program of explosive tests designed to determine the underwater pressure field from a specially shaped charge exploded in air. This report presents a preliminary analysis of the potential of this special test configuration for inflicting unwanted fish-kill. This analysis is restricted to swimbladder fish and is based on the data and method developed in Reference 1.

The method consists of an approximate calculation for the extreme values of compression and extension of the fishes' gasfilled swimbladder in response to the explosion pressure wave. The calculations are made for the damped radial oscillations of a spherical air bubble in water. The kill probability is then calculated as an experimentally determined function of the ratio of maximum to minimum radius during the oscillatory response.

Test Configuration. The test configuration is equivalent, for the purposes of this report, to a cylinder of $\mathrm{H}-6$ explosive (length/diameter ratio $=3.65$, axis vertical) centrally initiated at a scaled height, $\mathrm{h} / \mathrm{w}^{1 / 3}=0.182 \mathrm{~m} / \mathrm{kg}^{1 / 3}$, above the water surface. Tests using three different explosive weights - 8, 1000 , and $64,000 \mathrm{lb} \mathrm{H}-6$ - are considered. Table 1.1 lists the pertinent test parameters.

1. Goertner, J. F., "Dynamical Model for Explosion Injury to Fish," NSWC/WOL TR 76-155, Mar 1978. 


\begin{tabular}{|c|c|c|c|}
\hline Explosive Weight* & $\begin{array}{c}8 \mathrm{lb} \\
(3.63 \mathrm{~kg})\end{array}$ & $\begin{array}{ll}1000 & \mathrm{lb} \\
(450 & \mathrm{kg})\end{array}$ & $\begin{array}{l}64,000 \mathrm{lb} \\
(29,000 \mathrm{~kg})\end{array}$ \\
\hline Linear scale Factor & $1 / 20$ & $1 / 4$ & 1 \\
\hline Height of Burst** & $0.28 \mathrm{~m}$ & $1.40 \mathrm{~m}$ & $5.60 \mathrm{~m}$ \\
\hline
\end{tabular}

* H-6 explosive, RDX/TNT/AL/WAX (45/29/2l/5).

** Measured to point of initiation at center of charge.

Section 2 outlines the method used for this analysis. section 3 gives the method and some of the details of the calculations. Sections 4 and 5 present the results and conclusion of this study.

\section{METHOD}

The method followed in this study was to start from underwater pressure-time signatures measured on 8-1b tests. Figure 2.1 shows the complete set of pressure signatures measured on three identical tests. ${ }^{2}$

Selected pressure signatures were scaled up to the 1000-1b and 64,000-1b test configurations and were then used to calculate kill-probablilites for particular sizes and species of swimbladder fish. (Since the 8-lb tests were carried out in a small test pond, fish-kill was not calculated for this scale.)

The pressure signatures selected for kill-probability calculations were those at the greatest horizontal range from the charge (see Figure 2.1), since these are the most important for estimating the extent of the region of significant kill. We then compared the calculated kill probabilities for the 1000-lb and the 64,000-1b air burst tests with kill probabilities calculated for comparable underwater explosion tests.

2. Limited report by J. F. Pittman, Jan 1978; regarding DAWS POND Program II. A replicate set from the closest-in string of gages which was obtained on the opposite side of the charge has been omitted from the figure. 


\section{CALCULATIONS}

3.1 PRESSURE-TIME INPUTS. The first step in these calculations was to sketch-in average curves for the three sets of pressure-time signatures at the greatest horizontal range $(3.66 \mathrm{~m})$ shown in Figure 2.1. These average curves were then approximated either by two successive exponentials or by a square step followed by an exponential, since these simple wave forms could be calculated by the method presented in Reference 1 .

These approximating pressure-time signatures were then scaled up from $8 \mathrm{lb}$ to $1000 \mathrm{lb}$ and $64,000 \mathrm{lb}$-- the corresponding distances and times were increased in the ratio of the linear scale factor (or $\mathrm{w}^{1 / 3}$ ) and pressures were held constant. The scaled approximating pressure-time signatures for the 1000-1b and 64,000-1b test configurations are shown in Figures 3.1 .1 and 3.1 .2 , respectively. As in Reference 1 the exponential portions were calculated using two separate exponential segments joined at $t=1.8 \theta$

$$
\begin{array}{ll}
p=\operatorname{PMAX} e^{-t / \theta} & (t \leq 1.8 \theta) \\
p=0.25 \operatorname{PMAX} e^{-t / 4.3 \theta} & (t>1.8 \theta)
\end{array}
$$

The parameter $\theta$ was taken as the time for the measured pressure to drop to $1 /$ e of its peak value, PMAX.

3.2 REPRESENTATIVE FISH SPECIMENS. The fish selected for this study were striped Bass (or Rockfish) and White Perch. These are the fish expected to be present during the 1000-lb tests in the Potomac River during April, May, and June, at the Dahlgren test site of the Naval Surface Weapons Center. For each species a single representative size was selected for this study -- 38-cm fork length for striped Bass, 17-cm for White Perch. In addition, calculations were done for $21.5-\mathrm{cm}$ White Perch in order to compare kill probabilities calculated for the air burst tests with kill probabilities previously calculated for charges detonated underwater (Reference 1). Table 3.2.1 summarizes the fish input data for these calculations. 

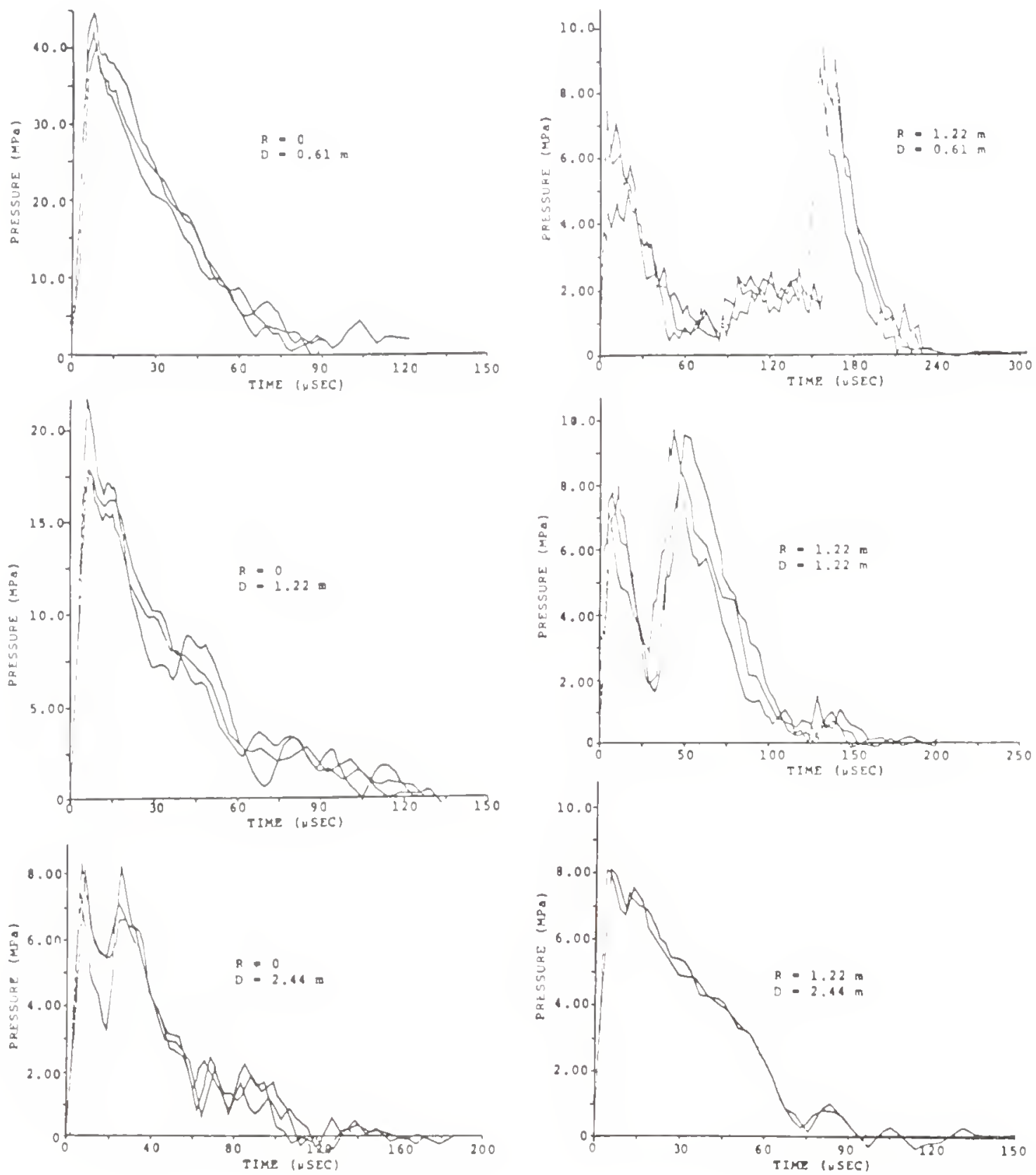

FIG. 2.1 UNDERWATER PRESSURE-TIME SIGNATURES MEASURED ON 8-LB TESTS

( $\mathrm{HOB}=0.28 \mathrm{~m})$ 

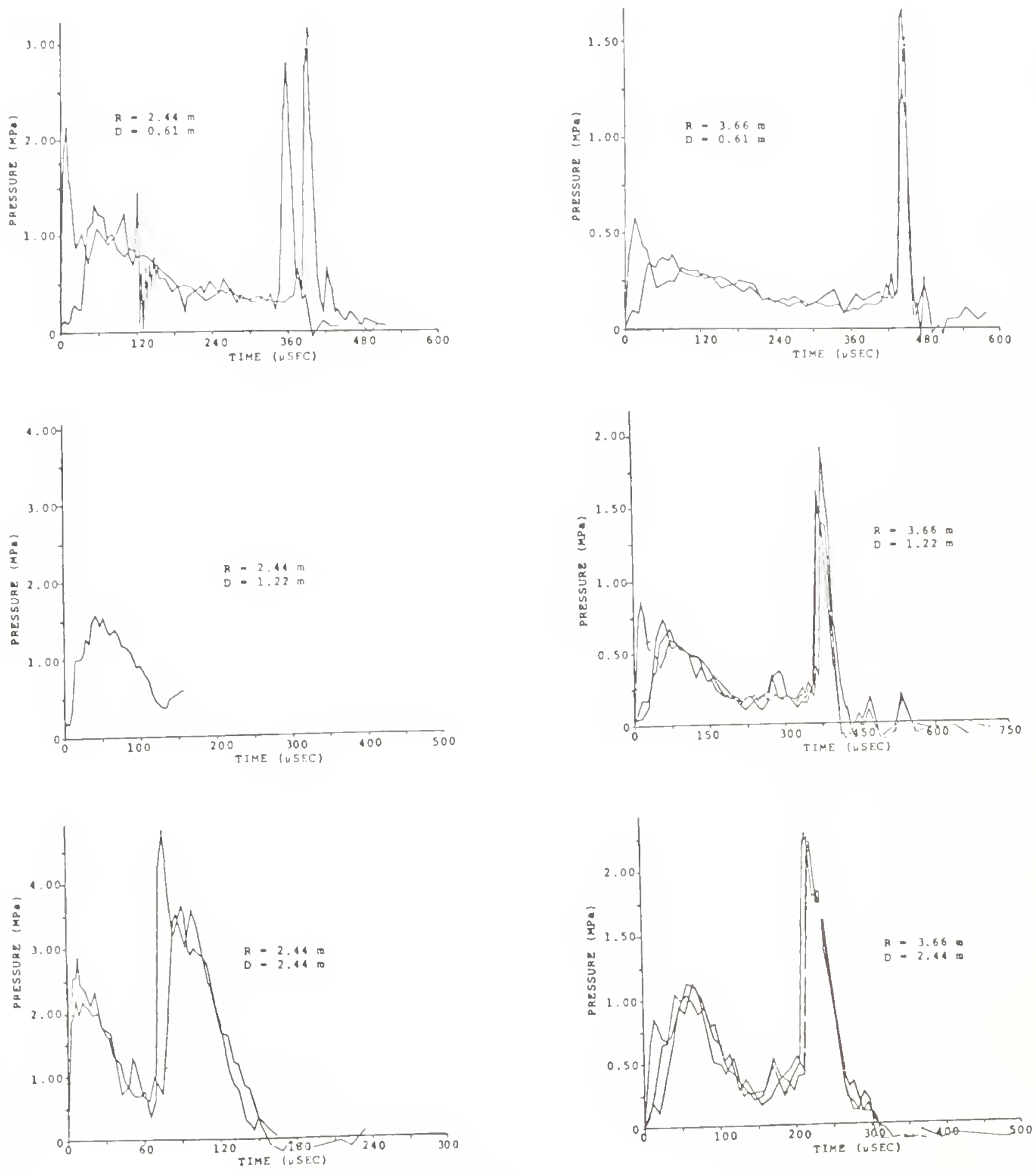

FIG. 2.1 (CONTINUED) 

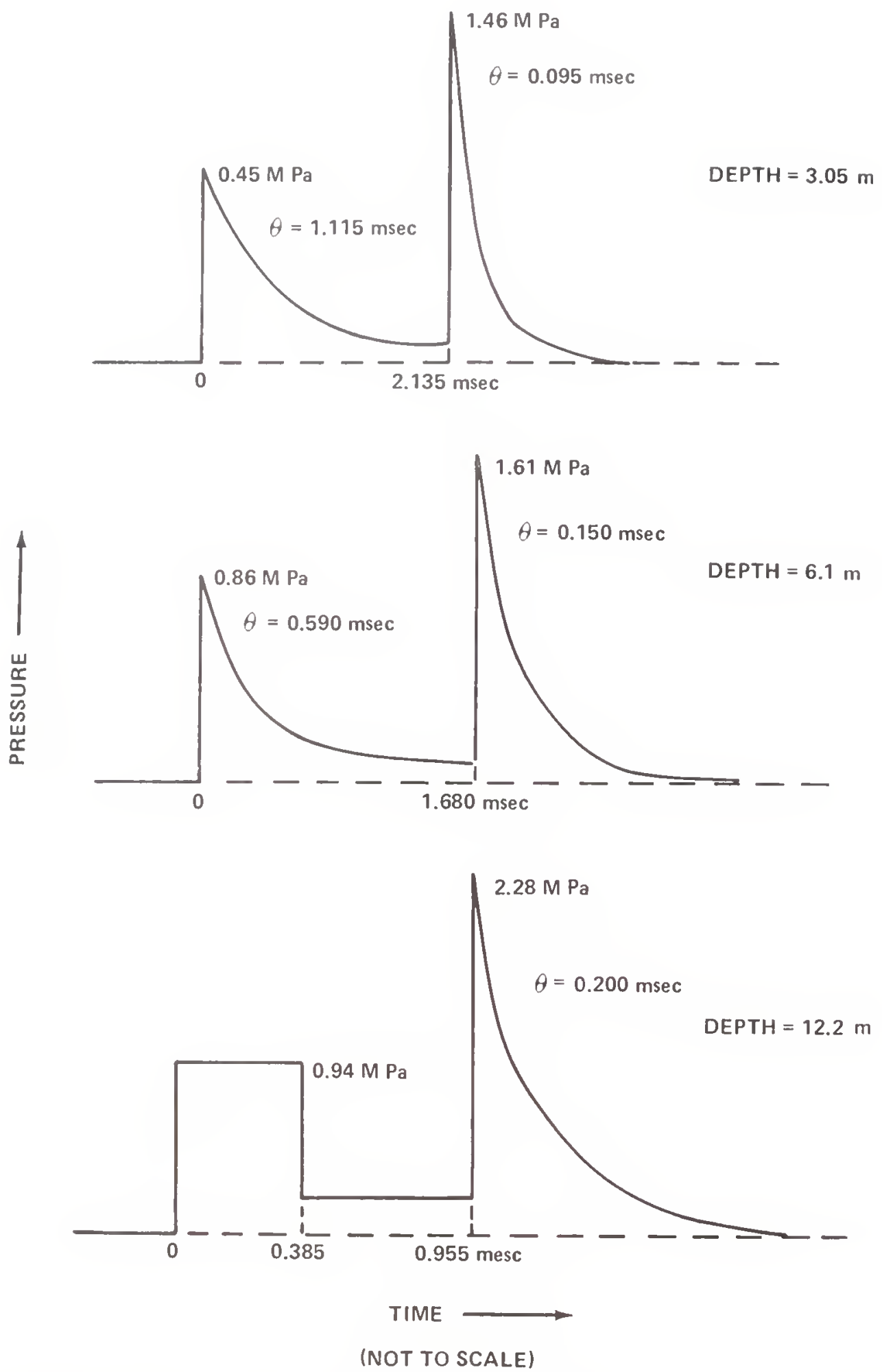

FIG. 3.1.1 SKETCH SHOWING PRESSURE-TIME SIGNATURES USED TO CALCULATE KILL PROBABILITIES (1000 LB H-6 ; HORIZONTAL RANGE = 18.3 METERS) 

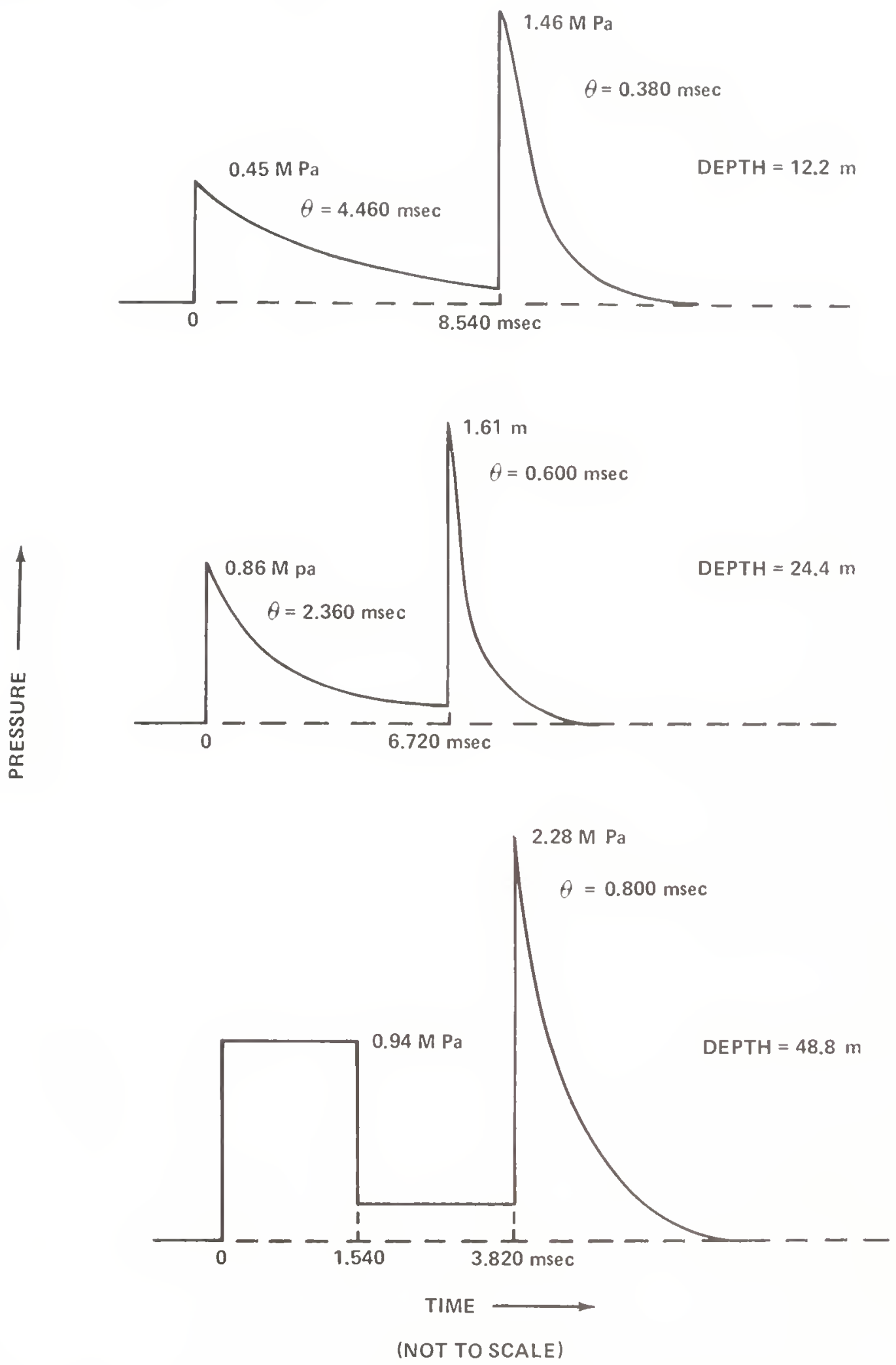

FIG. 3.1.2 SKETCH SHOWING PRESSURE-TIME SIGNATURES USED TO CALCULATE KILL PROBABILITIES (64,000 LB H-6; HORIZONTAL RANGE = 73.2 METERS $)$ 
Table 3.2.1. Fish Input Parameters

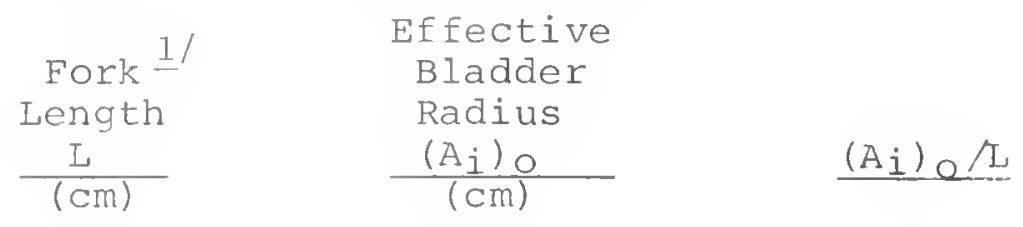

$\begin{array}{llcl}\text { Striped Bass } & 38 & 1.60 & 0.042^{2 /} \\ \text { White Perch } & 17 & 0.94 & 0.055^{3 /} \\ \text { White Perch } 1 \text { / } & 21.5 & 1.18 & 0.055\end{array}$

1 The length measured from the most anterior part of the head to the deepest point of the notch in the tailfin.

2/Reference 1, Equation 4.2.1

$\underline{3} /$ Reference 1 , Equation 3.1 .8

$\underline{4} /$ For comparison with underwater burst calculations

3.3 KILL PROBABILITY CALCULATIONS. These were done by the method presented in Reference 1. Basically, this consists of calculating the damped oscillatory response (radial oscillations) of a spherical air bubble corresponding to the fishes' swimbladder. This oscillatory response supplies the calculated damage parameter

$$
\mathrm{Z}=\mathrm{X}+\mathrm{Y}
$$

where

$$
\begin{aligned}
& X=-100 \ln \mathrm{AMIN} / \mathrm{A}_{i} \\
& \mathrm{Y}=100 \ln \mathrm{AMAX} / \mathrm{A}_{i}
\end{aligned}
$$

Where $\ln$ is the natural logarithm, $A_{i}$ is the initial at-rest bubble radius, and AMIN and AMAX are the smallest and largest radii during the oscillatory response.* Note, that we choose not to combine Equations 3.3.1,2,3 into $\mathrm{z}=100 \mathrm{ln}$ AMAX/AMIN in order to emphasize the fundamental independence of the damage parameter components, $X$ and $Y$.

\footnotetext{
"In this study AMAX occasionałly occurred prior to AMIN, and this was permitted even though this has not happened under the testing conditions studied to date. (However, had we not used the occasional AMAX values occurring prior to AMIN the results of this study would still be, for practical purposes, identical.)
} 
The kill probability, $p$, is then calculated as

$$
p=\frac{1}{1+\operatorname{ExP}[-0.055(z-125)]}
$$

This equation represents underwater explosion test data from some 1500 caged spot and White Perch over a wide range of explosive test conditions. Equation 3.3.4 was used for predicting the striped Bass kill as well as for white Perch, since unpublished preliminary results with 16 species of fish indicate that Equation 3.3.4 applies to the majority of swimbladder fish.**

3. 4 RESPONSE TO EXPONENTIAL WAVES OF SHORT DURATION. The method used in Reference 1 to calculate the oscillatory response to exponential waves was to patch together solutions to successive square steps of half-period duration. This solution breaks down, however, as the time constant $\theta$ becomes less than the duration of the calculated first half-period of the motion, and the calculated size of the first compression gets too small. This comes about because, in the limit as $\theta$ becomes smaller and smaller, the first approximating step takes on the value one-half PMAX, the average of the initial and final pressures-and consequently, the damage parameter, $x=-100$ In $A M I N / A_{i}$, does not go to zero as $\theta$ approaches zero.

Impulsive Loading Approximation. This approximation is for the limiting case of pulses of infinitely short duration. Under impulsive loading the initial radial velocity $v_{i}$ of the bubble is given by

$$
v_{i}=-\frac{I}{\rho \bar{A}_{i}}
$$

\footnotetext{
*Reference 1, Equation 3.2.1
}

*Equation 3.3 .4 describes explosion test results for 10 of the 16 species tested. The other 6 species required larger values for $\bar{Z}(=125$ in Equation 3.3.4). 
where $p$ is the density of the water and $I=\int p d t$, the applied impulse. ${ }^{3}$ In order to extend the range of usefulness of this approximation we compute the applied impulse at $t=0$ as

$$
\begin{aligned}
I & =\int_{0}^{\theta} p(t) d t \\
& =\operatorname{PMAX} \times \theta \times\left[1-e^{-1}\right] \\
& =0.632 \times \operatorname{PMAX} \times \theta
\end{aligned}
$$

The total energy $Y$ following impulsive loading is given by *

$$
Y=\frac{3}{2} \rho V_{i} V_{i}^{2}+p_{i} V_{i}+\frac{p_{i} V_{i}}{\gamma-I}
$$

where $\mathrm{p}_{i}$ and $\mathrm{V}_{i}$ are the initial pressure and volume of the bubble, and $\gamma$ is the adiabatic exponent (= 1.4 for air). In Equation 3.4.3 the first term is the kinetic energy imparted to the surrounding water by the impulsive loading, the second the potential energy of the surrounding water, and the third the internal energy of the air inside the bubble.

From the total energy $Y$ we calculate the dimensionless bubble oscillation parameter $k$ used to describe the motion

$$
k=\frac{1}{\gamma-1}\left(\frac{Y}{p_{i} V_{i}}\right)^{-\gamma}
$$

Combining 3.4.1, 3.4.3, and 3.4.4 we can express $k$ in terms of the impulse and initial bubble radius

\footnotetext{
* Reference 1, Equation A1

** Reference 1, Equation A13

3. Kennard, E. H., 1943, "Radial Motion of Water Surrounding a Sphere of Gas in Relation to Pressure Waves," published in Vol. II of "Underwater Explosion Research," Office of Naval Research, 1950.
} 


$$
k=\frac{1}{\gamma-1}\left[\frac{\gamma}{\gamma-1}+\frac{3}{2}\left(\frac{1}{A_{i} \gamma \rho p_{i}}\right)^{2}\right]^{-\gamma}
$$

Damage Parameters $X$ and $Y$. The problem is to calculate the damage parameters $X$ and $Y$, Equations 3.3 .2 and 3.3 .3 , respectively. Thus we must calculate $A M I N / A_{i}$ and $A M A X / A_{i}$. We proceed as follows. First, using $\mathrm{k}$ (Equation 3.4.5) we look up AMIN/AMAX in Table A-1 of Reference 1. Next, we calculate the pressure ratio ${ }^{4}$

$$
\frac{\text { PMIN }}{P_{i}}=\frac{(\gamma-1)\left[1-\left(\frac{\text { AMIN }}{\overline{A M A X}}\right)^{3}\right]}{\left(\frac{\text { AMIN }}{\text { AMAX }}\right)^{3}\left[1-\left(\frac{\text { AMIN }}{\text { AMAX }}\right)^{3(\gamma-1)}\right]}
$$

where PMIN is the air pressure at the first compression.

Finally, using the adiabatic pressure-volume relationship we get

$$
\frac{A M I N}{A_{i}}=\left(\frac{\text { PMIN }}{p_{i}}\right)^{-\frac{1}{3 \gamma}}
$$

and

$$
\frac{A M A X}{A_{i}}=\left(\frac{A M I N}{A_{i}}\right) /\left(\frac{A M I N}{A M A X}\right)
$$

With increasing $\theta$ both the first compression and the subsequent expansion calculated by this approximation become too 1 arge. Thus both damage parameters, $x=-100 \ln A M I N / A_{i}$ and $y=100 \ln$ AMAX/A, become progressively too large with increasing values of $\theta$.

\footnotetext{
4. Snay, H. G. and Christian, E. A., 1952, "Underwater Explosion Phenomena: The Parameters of a Non-Migrating Bubble Oscillating in an Incompressible Medium," NAVORD Report 2437, Equation 14a.
} 
Which Approximation to use. For those cases where the calculation by half-period square steps showed $\theta$ to be the order of a half-period or less, we calculated the fish damage parameter, $Z=X+Y$, by both approximations. Since the systematic errors in both of these approximations result in values of $z$ which are too high--square steps for $\theta$ values too small, impulse for $\theta$ values too large--we calculated these cases by both approximations and selected the one giving the smallest value of the damage parameter 2 . It turned out that the crossover for the $z$ values calculated by the two approximations occurred for $\theta$ values equal to approximately six-tenths of the first half-period calculated by square steps.

3.5 PATCHING OF SOLUTIONS. The response of the equivalent bubble to the pressure-time signature was determined separately for each of the two pulses shown in Figures 3.1.1 and 3.1.2. To facilitate the calculations the response to the second pulse was calculated as starting from rest at the initial ambient radius and pressure, $A_{i}$ and $p_{i}$. Results of the separate calculations were then scanned to obtain the extreme values of the radius, AMIN and AMAX. Table 3.5.1 sumarizes the results of these calculations. The values of $X$ and $Y$ selected to calculate the damage parameter, $Z=X+Y$, are indicated with a check mark. Note that the value of $X$ or $Y$ selected is the maximum of the value calculated for the first pulse and that second pulse value corresponding to the method of calculation--square or impulsive loading--selected according to the criterion given in section 3.4. For example, for the first entry (first row) in Table 3.5.1, the "Impulsive Loading" calculation was used for the second pulse, since this value of $Z=X+Y(48+38)$ is less than the value calculated by "Square Steps" $(102+40)$. Thus, the value for $z$ representing the combined response to the first and second pulse is the sum of 64 , the greatest $x$ value (taken from first pulse having discarded the value 102 ), and 38 , the greatest $y$ value (taken from second pulse having discarded the value $\underline{40}$ ).

Additional Details. Response to the first pulse for the two shallowest depths (Figures 3.1.1 and 3.1.2) was calculated by the method of Reference 1 by setting TPOS (Reference 1, Figure 3.1.1) equal to the time of arrival of the second pulse. Response to the first pulse (square step) for the deepest depth was calculated setting PMAX equal to the step pressure and $\theta$ equal to approximately $10^{6}$ times the duration of the step. Other parameters were cet as follows: TFOS = step duration, PNEG = plateau pressure following step, and DTNEG = duration of plateau pressure. 
NSWC/WOL TR 77-90

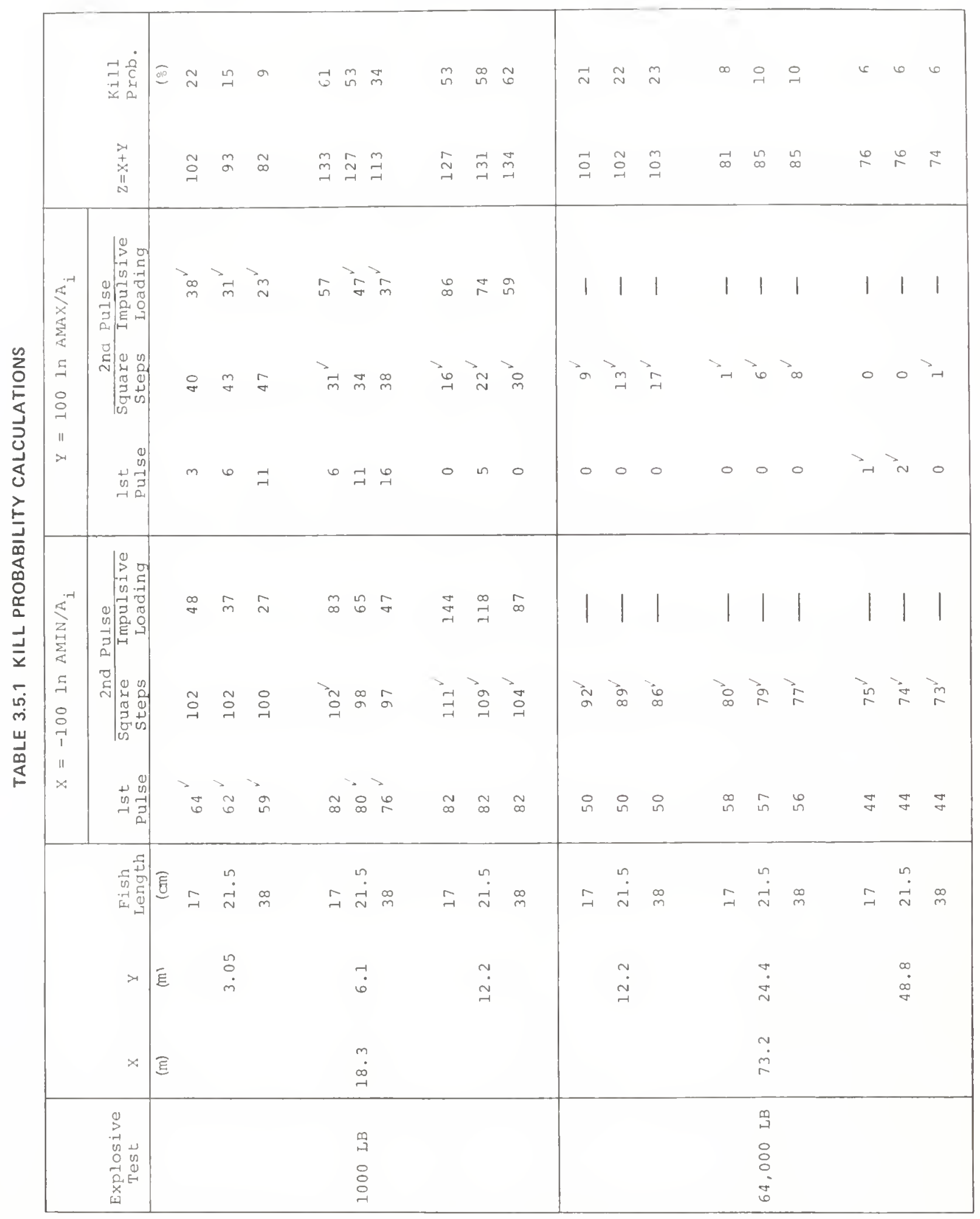


Response to the second pulse at all depths was calculated both by the method of Reference 1 (square steps) and by the impulsive loading approximation described in section 3.4. As described in Section 3.4, the method giving the smallest value for $Z=X+Y$ was then selected to represent the response to the second pulse.

\section{RESULTS}

4.1 GENERAL OBSERVATIONS. The final column of Table 3.5 .1 lists the kill probabilities corresponding to the calculated fish damage parameter $\mathrm{Z}$ for the representative 1000-1b and 64,000-1b test conditions selected for this study. Relative to the uncertainties inherent to this study, the variation of kill probability with fish size is not great. This factor of two variation at the two shallowest locations for the 1000-1b test geometry is largely due to the variable response of the different sized swimbladders to impulsive loading by the second pressure pulse.

One would expect the longer duration pressure pulses of the 64,000-1b test geometry to cause larger kill probabilities at corresponding scaled locations. Except for the marginal case of the shallowest gage location this does not occur, since the effect of 4 times greater depth at corresponding scaled locations on the 64,000-1b test more than offsets the effect of longer pulse durations. This generally lesser kill probability at corresponding locations of the 64,000-1b test geometry is a direct result of increased hydrostatic pressure suppressing the amplitude of swimbladder oscillation.

4.2 KILL PROBABILITY CONTOURS. To give meaning to these kill probability results we compare them to similar calculations for underwater explosions. Figures 4.2.1 and 4.2.2 show contours of constant kill probability calculated for charge weights of 0.57 and $32 \mathrm{~kg}$ pentolite respectively, exploded at a depth of 9 meters.*

\footnotetext{
*H-6 is more energetic than pentolite. It probably takes about 1.1 to 1.2 times as much pencolite on a weight basis to produce roughly equivalent underwater pressure fields in the air-burst and underwater-burst configurations considered in this report "No "equivalent weight" corrections were made in doing the compari-
} 
The three kill probabilities calculated at each air burst test geometry-- 1000-1b and 64,000-1b--are also shown (enclosed by solid circles) on Figures 4.2.1 and 4.2.2. In the following paragraphs we will use these plots to make order-of-magnitude estimates of the fish-killing potential of these four explosion test geometries.

The computed kill probability data for the underwater explosions is more complete than that for the air bursts. For the purposes of this report the author has sketched in (dashed curves, Figures 4.2.1 and 4.2.2) possible extrapolations to the 50\% and $10 \%$ kill contours. These extrapolations are made in lieu of further computations because they do not affect the order-of-magnitude conclusions of this report. (were it required, the author does not foresee any difficulty in extending these contours by further computations to shallower depths and also to the region directly beneath the charge.)

For the air burst tests our data is meager. About the best we can do is a crude estimate for a single kill probability contour for each test configuration. For the 1000-lb air burst test (Figure 4.2.1) we take as an estimate for the region of greater than $50 \%$ kill the shaded area--a cylinder of water 20 meters in radius and 25 meters deep.

In order to estimate the lower boundary for $50 \% \mathrm{kill}$ on the 1000-1b air burst test we needed more than the three kill probabilities listed inside the solid circles (Figure 4.2.1). Thus, in order to estimate the falloff of the kill probability with increasing depth we calculated what is probably an upper bound by using the pressuretime signature measured at the deepest gage (Figure 3.1.1) and calculating the kill probability corresponding to this signature as a function of hydrostatic pressure (different fish depths). The kill probabilities 1isted inside the dashed circles of Figure 4.2.1 were obtained this way. (Table 4.2 .1 gives the complete results of these calculations where only the fishes' depth was varied.)

For the 64,000-1b air burst test we take as an estimate for the region of greater than $10 \% \mathrm{kill}$ a cylinder of water 70 meters in radius and 50 meters deep (shaded area, Figure 4.2.2). 


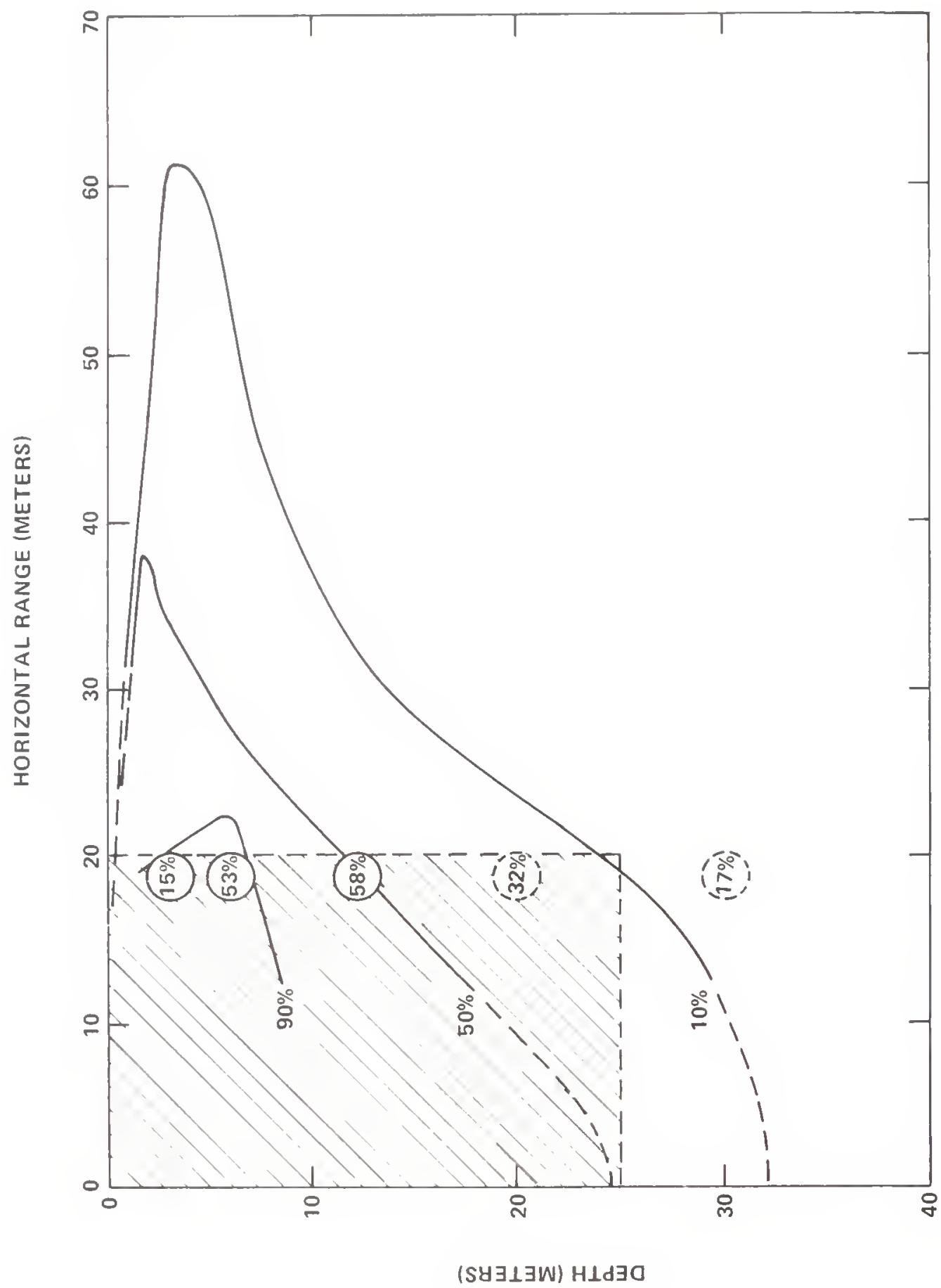

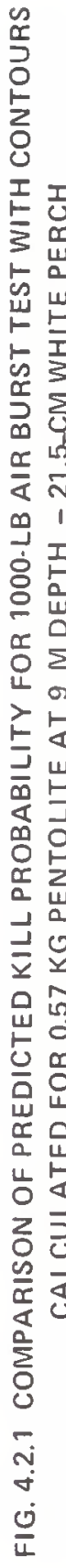


HORIZONTAL RANGE (METERS)

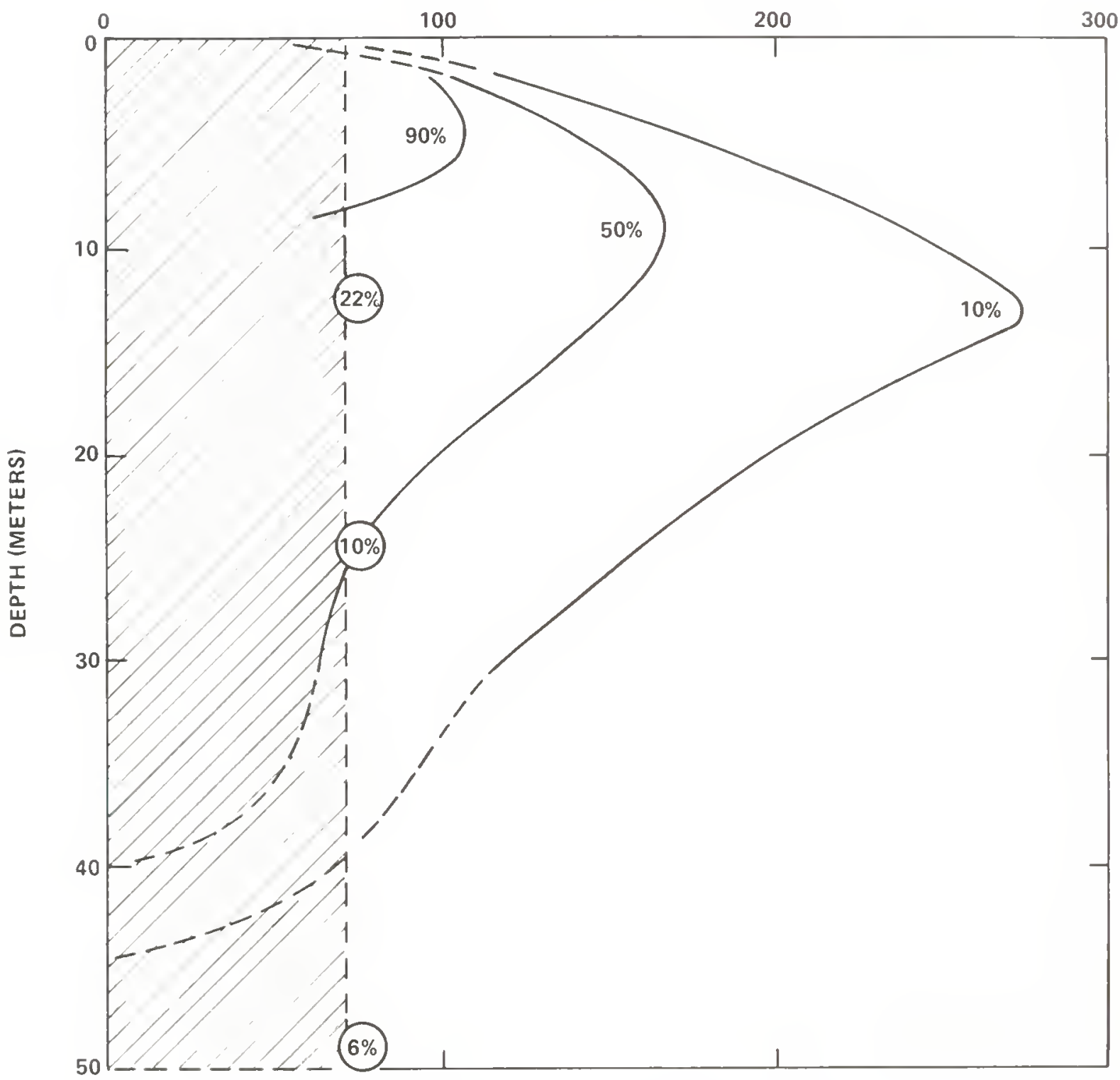

FIG. 4.2.2 COMPARISON OF PREDICTED KILL PROBABILITY FOR 64,000-LB AIR BURST TEST WITH CONTOURS CALCULATED FOR 32 KG PENTOLITE AT 9 M DEPTH - 21.5-CM WHITE PERCH 


\section{Table 4.2.1.}

Variation of Kill Probability as a Function of Fishes' Depth

$$
\text { 21.5-cm White Perch }
$$

$$
p(t)=\operatorname{PMAX} e^{-t / \theta}: \operatorname{PMAX}=2.28 \mathrm{MPa}, \quad \theta=0.200 \mathrm{msec}
$$

$\frac{\text { Depth }}{\text { (meters) }}$

$$
10
$$

20

30

40

50

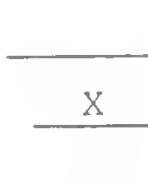

113

93

80

71

63
Fish Damage Parameters

\section{$\underline{Z}=\mathrm{X}+\mathrm{Y}$}

137

111

96

84

76
Kill

$\frac{\text { Probability }}{(0)}$

65

32

17

10

6 
4.3 NOMINAL FISH KILL. In order to assess the fish-killing potential of an explosion we define a "Nominal Fish Kill" based on an assumed uniform fish density distribution of $10^{-3}$ fish of specific species and size per cubic meter of water. Thus, to calculate the Nominal Fish Kill we compute the $\int \mathrm{p} d v$ where $\mathrm{p}$ is the calculated kill probability and multiply by the assumed uniform fish density, i.e.,

$$
\text { Nominal Fish } \mathrm{Kill}=10^{-3} \int \mathrm{p} d v
$$

where $\mathrm{v}$ is the water volume in meters.

We now wish to calculate the Nominal Fish Kill for the four explosion test geometries described by Figures 4.2.1 and 4.2.2. To do this we approximate $\int \mathrm{p} d v$ (Equation 4.3 .1 ) by the volume of water enclosed by the 50\%-kill contour.* Table 4.3.1 lists the calculated water volumes enclosed by the 50\% and $10 \% \mathrm{kill}$ contours for the four explosion geometries. The calculated volumes for the underwater explosions were used to estimate an average value of the volume ratio, 50\%-to-10\% kill, (= $33 \frac{1}{2} \%$ ) which we then used to estimate the 50\% kill volume for the full scale air burst test (Figure $4.2 .2)$.

The Nominal Fish Kill values calculated from these $50 \% \mathrm{kill}$ volumes (Table 4.3.1, first column) are listed in Table 4.3.2.** The final column of Table 4.3.2 lists the Nominal Fish Kill per kilogram of explosive used. Thus, on a fish/kg basis the underwater shots are some 1000 times more effective in killing fish than the air burst test configurations.

*This approximation underestimates $\int \mathrm{p} d v$. For the example worked out in Table 4.3.1 of Reference 1 (same set of calculations as used here for the $32 \mathrm{~kg}$ underwater explosion) this approximation results in a value for Nominal Fish Kill which is $89 \%$ of the value obtained thru the approximate integration described by the Table. For the underwater explosions, volumes enclosed by the contours were calculated by suming cone frustrum elements which approximated successive slices of the figure of revolution.

**Alternatively, we could describe the fish killing potential in terms of a Mean Kill Volume $=\int p d v$. (See Appendix A.) Thus, the Nominal Fish Kill is simply the Mean Kill Volume expressed in thousands of cubic meters of water. 
Table 4.3.1. Water Volumes Enclosed by Kill Probability Contours (Thousands of Cubic Meters)

Kill Probability Contour $\quad \frac{50 \% \text { Vol. }}{10 \% \text { Vol. }}$

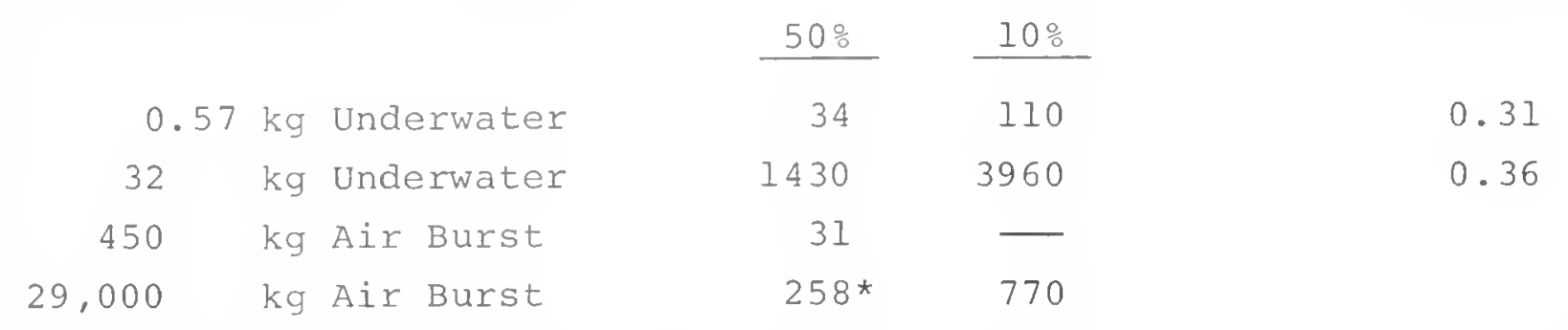

*Estimated value $=33 \frac{1}{2} \%$ of $10 \% \mathrm{Kill}$ Volume

Table 4.3.2. Estimated Nominal Fish Kill

Assumption: Uniform Fish Density $=10^{-3}$ Fish/(Meter) ${ }^{3}$

\begin{tabular}{ll} 
Nominal & Nominal \\
Fish Kill & Kill/kg \\
\hline
\end{tabular}

$\begin{array}{rrrc}0.57 & \mathrm{~kg} \text { Underwater } & 34 & 60 \\ 32 & \mathrm{~kg} \text { Underwater } & 1430 & 45 \\ 450 & \mathrm{~kg} \text { Air Burst } & 31 & 69 \times 10^{-3} \\ 29,000 & \mathrm{~kg} \text { Air Burst } & 260 & 9 \times 10^{-3}\end{array}$


NSWC/WOL TR 77-90

\section{CONCLUSION}

On a fish-killed/kg explosive basis a typical underwater explosion is some 1000 times more hazardous for killing fish than the two air burst test geometries considered. 

An alternative measure of the fish-killing potential of an explosion geometry is the Mean Kill Volume (or MKV) defined on the basis of an assumed uniform spatial distribution of fish. Let D be the assumed uniform spatial density for fish of a given species and size. Assuming $D$, let $N$ be the number of fish killed by a given explosion geometry. We then define the mean kill volume by

$$
\mathrm{MKV}=\mathrm{N} / \mathrm{D}
$$

Thus, the mean kill volume is the volume of water which multiplied by the assumed uniform fish density results in the number of fish killed by the explosion.

Since $N$ is generally computed by

$$
\mathrm{N}=\int \mathrm{P} \times \mathrm{D} d \mathrm{~V}
$$

Where $\mathrm{p}$ is the kill probability, we can also express the mean kill volume directly in terms of the kill probability

$$
\mathrm{MKV}=\int \mathrm{p} d \mathrm{~V}
$$

In this way we can avoid referencing the fish density distribution which is generally unknown.

Given an approximately random distribution of fish the MKV is an appropriate parameter for comparing the fish-killing potential of explosion test configurations. *

*If one has specific knowledge of the fish density distribution, such as the presence of only bottom-feeding or surface-feeding fish then this additional knowledge should, of course, be used.

$$
A-1 / 2
$$



DISTPIBLTION

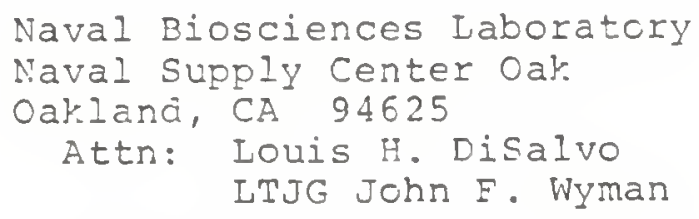

Commanding officer

Naval Underwater systems Center

Newport, RI C2840

Attn: Roy R. Manstan, Code EA 11

Naval Ship Research and Development Center

Underwater Explosions Research Division

Portsmouth, VA 2370 9

Attn: LCDR R. H. Burt

R.ichard Oliver

Commander

Naval Ocean Systems Center

San Diego, CA 92152

Attn: G. B. Anderson

S. Yamamoto, Code 405

[. A. Wilson

F. G. Wood, code 40

Code 6565

Michael H. Salazar

Jack W. Hoyt

J. D. Warner, Code 2531

William C. Cummings, Ccde 4013

Naval Ccean Systems Center

Hawaii Laboratory

P.O. Box 997, Kailua, Oahu

Hawai, 96734

Attn: Evan C. Evans, III

Head Marine Environmental Management Office

Officer in Charge

New London Laboratory

Naval Underwater Systems Center

New Loncon, CT 06320

Attn: Albert B. Brooks

Charles L. Brown, Jr., Code TAI3

Commancing officer

Naval Explosive Ordnance Disposal Facility

Ir.dian Head, MD 20640

Attn: Library Livision

Iionel A. Dickinson, Code 5D

P.ichard Eurdette

Iy le ralotky 
Commanding ofeicer

Naval Explosive Ordnance Disposal School

Indian Head, MD 20640

Attn: LCDR E. W. MCConnell

Commancer

David $w$. Taylor Naval Ship Research

and Development Center

Bethesda, MD 20034

Attn: Library, Code 5641

Commanding officer

Naval Coastal Systems Laboratory

Panama City, FI 32401

Attn: Code 350

John A. Brasewe11, Code 773

Everett L. Richards, code 721

Officer in Charge

Civil Engineering Laboratory

Naval Construction Battalion Center

Port Hueneme, CA 93043

Attn: coce L 70

Code I7I

Code $\mathrm{I} 43$

code L65

Commanding officer

Naval Air Station

Patuxent River, MD 20670

Attn: F. I. Clark, Environmental Protection Coordinator

Public Works Department

Commander

Naval Sea Systems Command

Washington, D. C. 20362

Attn: SEA-033

$S E A-0332$

$S E A-332 B$

$S E A-09 G 32$

$S E A-03 B$

U. S. Army Engineer District

100 McAllister Street

San Francisco, CA 94102

Attn: Tom crews, III, Environmental Branch

Edgewood Arsenal

Edgewood, MD 21010

Attn: David kramer

Harold Sommer

Allen E. Hilsmeier 
U. S. Army Engineer Division, Pacific ocean

Environmental Section

Eldg. 230, Ft. Shafter

APO San Erancisco 96558

Attn: Michael T. Lee, Biclogist

Director

Waterways Experiment Station

P. O. BOX 631

Vicksburg, MS 39180

Attn: Tectnical Library

J. N. Strange

Kim Davis

WIESNE

ADTC/DLV

Eglin AFB, EL 32542

Attn: J.C. Cornette

National Marine Fisheries Service

Auke Bay Biological Laboratory

P. O. Eox 155

Alike Bay, AK 99821

Attn: Theodore Merrell

Naticnal Marine Fisheries Service

Water Resources Division

P. O. Box 1668

Juneau, AK 99801

Attn: Dale R. Evans, Chief

National Marine Fisheries Service

Southwest Fisheries Center

P. O. BOY 271

La Jolla, CA 92037

Department of Commerce

National Oceanic and Atmospheric Administration

Washington science Center, Blag. 5

6010 Executive Blvd.

Rockvilie, MD 20852

Attn: Donald P. Martineau, Deputy Associate Administrator for Marine Resources

CAFT Scott E. Drummond, Room 918

CDR John G. McMillan, USN

ITJG Richara A. Zachariason, Room 805

Sidney T. Smith, Room 100

Milton S. Arrostam

Emmett S. Hill, Jr.

Fletcher F. Echard, A.D $1 \times 3$ 
Department of Commerce

Biological Laboratory

Milford, CT 06460

Department of the Interior

$2107 \mathrm{NF} 45$ th Street

Suite 110

Seattle, WA 98105

Attn: Karen Bachman

Mark L. Holmes

Department of the Interior

Eureau of sports Fisheries and Wildife

Interior Building

washington, D. C. 20240

Attn: John S. Gottschalk, Director

Bureau of Commercial Fisheries

Interior Building

Washington, D. C. 20240

Attn: Philip M. Roedel, Director

State of Maryland

Fish and Wildife Administration

Annapolis, MD 2.1404

Attn: Charles Frisbie

Barbara Holden

State of North Carolina

Department of latural and Economic Resources

Division of Marine Fisheries

Box 769

Morehead City, NC 28557

Attn: Willard Lane, Artificial Peef Program

Jim Tyler, Artificial Reef Program

South Carolina Marine Resources Division

2024 Maybank Highway

Charleston, SC 29412

Attr: Michael D. Mckenzie

Trust Territory Environmental Protection Boarc

P. o. Bor. 215

Yap, F.C.I. 96943

Attn: M. Falanruw, Staff Ecologist

Howard J. King, E-2

580 Tayler Avenue

Annapolis, MD 21401 
State of Alaska

Department of Fish and Game

333 Raspberry Road

Anchorage, AK 99502

Attn: Lance L. Trasky, Fisheries Research Biologist

Deputy Commissioner

Alaska Department of Fish and Game

Support Building

Juneau, AK 99801

Attn: Joseph R. Blum

State of Alaska

Department cf Fish and Came

Habitat Section

333 Raspberry Road

Archorage, AK 99501

Department of Fish and Game

Wildife Protection Branch

1416 Ninth Street

Sacramento, CA 95814

State of California

Marine Resources Division

350 Golden Shore

Long Peach, CA 90802

Attn: Doyle Gates, Regional Manager

State of Florida

Department of ratural Resources

Larson Building

Tallahassee, FI 32304

State of Louisiana

vildilife and Fisheries Commission

P. O. Box 44095, Capital Station

Baton Rough, IA 70804

Attn: Frec Dunham

Virginia Institute of Marine Science

Gloucester Point, VA 23062

Attn: William J. Hargis, Director

University of Washington

College of Fisheries

Fisheries Research. Institute

Seattle, Wy 98195

Attn: Dave R. Gibbons

Charles Simenstad, Biclogist 
Director

Woods Eole Oceanographic Institution.

woods Hole, MiA 02543

Attn: Bostwick Ketchum

Giffora C. Ewing

Earl E. Hays

Library

Director

Scripps Institution of Oceanography

La Jolla, CA 92037

Attn: Fred Spiess

Schocl of Oceanography

Oregon State University

Corvallis, OR 97331

Attn: A. G. Carey, Jr.

Librarian

Chesapeake Ray Institute

The Johns Hopkins University

Baltimore, MD 21218

Chesapeake Eiclogical Laboratcry

P. O. Box 38

Solomons, MD 20688

Attn: T. S. Y. K.co

Joseph A. Mihursky

Martin L. Wiley

John S. Wilson

Marine Prysical Laboratory, S10/UCSD

Bldg. 106, Naval Uncersea Center

San Diego, CA 92106

Attn: Charles B. Bishop

University of Hawaii at Manoa

Hawaii Institute of Marine Biology

P. O. Box 1346, Coconut Island

Kaneohe, HI 96744

Attn: George H. Balazs, Ir., Marine Riologist

Department of Biology

uuniata College

Huntingdon, PA 16652

Attn: Robert L. Fisher

Merine Resources Division

California state Fisheries Lab

350 South Mignolia

Long Eeach, CA 30802

Attn: Robert Kanlen 
Argus pressure Grouting Services, Inc.

22000 Ryan Road

Warren, MI 4809 I

Attn: Albin Gronowicz, President

Hydronatics

7210 Pindell school Road

Laurel, MD 20910

Attn: Norman Shapira

Pobert E. Eckels \& Associates

Consuiting Engineers

2101 Youngeield

Golden, CO 80401

Woodward clyde consultart

Eox 1149

Orange, $\mathrm{CA} 92668$

Attn: Jack Kiker

B.O.C. Sub Ocean Services

1022 Wirt Road

Houston, TX 77055

Attn: Thomas I. Kirchberg

Lovelace Eiomedical \& Environmental Research

Institute, Inc.

P. 0 . BOx 5890

Albuquerque, NN 87115

Attn: Donald R. Richmona

E. Royce Fletcher

Pobert K. Jores

John T. Yelverton

Nieteorology P.esearch, Inc.

464 West Woodbury Road

Altadena, CA 91001

Attn: George Woffinder

Mount Auburn Research Associates, Inc.

385 Eliiot street

Newton, MA C2164

Attn: Shelcon L. Kahalas

Tetra Tech, Inc.

630 N. Rosemead Blvd.

Pasadena, CA 91107

Attn: Ii-San Hwang

Explo precision Engineerirg Corporation

Nanager of Technical Services

Gretna, IA 70053

Attn: John J. Ridgeway 
Crisfield Laboratory

Eox 351

Crisfield, MD 21817

Attn: M. W. Paparelia

Defense Documentation Center

Cameron Station

Alexandria, VA 22314 
TO AID IN UPDATING THE DISTRIBUTION LIST

FOR NAVAL SURFACE WEAPONS CENTER, WHITE

OAK TECHNICAL REPORTS PLEASE COMPLETE THE

FORM BELOW:

TO ALL HOLDERS OF NSWC/WOL/TR 77-90

by John F. Goertner, Code R-14

DO NOT RETURN THIS FORM IF ALL INFORMATION IS CURRENT

A. FACILITY NAME AND ADDRESS (OLD) (Show Zip Code)

NEW ADORESS (Show $Z_{\text {ip }}$ Code)

B. ATTENTION LINE ADDRESSES:

C.

REMOVE THIS FACILITY FROM THE DISTRIBUTION LIST FOR TECHNICAL REPORTS ON THIS SUBJECT.

D. NUMBER OF COPIES DESIREO 


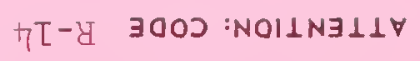

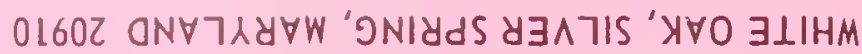
$\forall \exists \perp N \exists \supset$ SNOd $\forall \exists M \exists \supset \forall \sqsupset y \cap S 7 \forall \wedge \forall N$

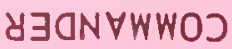

\section{TाषW'รก 918000}

$\wedge \wedge \forall N \exists H \perp \pm 0 \perp N \exists W \perp \forall \forall d \exists O$

OIVd $5 \exists \exists \exists$ ON $\exists$ I $150 d$

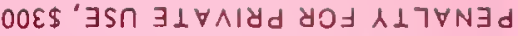

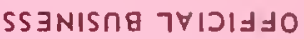

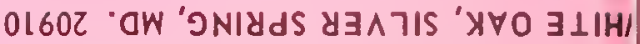

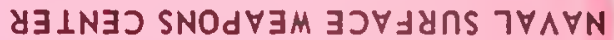
$\Lambda \wedge \forall N \exists H \perp$ JO $\perp N \exists W \perp d \forall d \exists O$ 
$a^{2^{3}}$ 


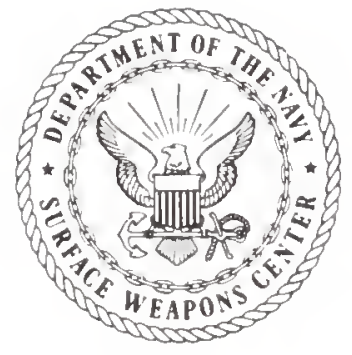

